\title{
Respective effects of milk composition and the cheese-making process on cheese compositional variability in components of nutritional interest
}

\author{
Anthony LUCAS ${ }^{\mathrm{a}, \mathrm{b}}$, Edmond ROCK ${ }^{\mathrm{c}}$, Jean-François CHAMBA ${ }^{\mathrm{a}}$, \\ Isabelle VERDIER-METZ ${ }^{\mathrm{d}}$, Patrick BRACHET ${ }^{\mathrm{c}}$, Jean-Baptiste COULON ${ }^{\mathrm{b}}$ \\ a Institut Technique Français des Fromages, 74801 La Roche-sur-Foron, France \\ b Unité de Recherches sur les Herbivores, Institut National de la Recherche Agronomique, \\ 63122 Saint-Genès-Champanelle, France \\ c Unité de Maladies Métaboliques et de Micronutriments, Institut National de la Recherche Agronomique, \\ 63122 Saint-Genès-Champanelle, France \\ d Unité de Recherches Fromagères, Institut National de la Recherche Agronomique,
} 15000 Aurillac, France

Received 4 April 2005 - Accepted 27 June 2005

\begin{abstract}
To assess the relationship between conditions of milk production and cheese contents of components of nutritional interest, it is necessary to know to what extent the compositional variability of cheese depends on that of milk. The respective effects of milk composition and the cheese-making process on cheese compositional variability in components of nutritional interest were therefore studied under real conditions of cheese production considering four different cheese-making technologies. The nutritional characteristics of the original milk were subject to high variations partly due to animal species (cow vs. goat). Apart from the aspects related to the dry matter content of cheese, the cheese compositional variability in fatty acids, $\beta$-carotene, xanthophylls and vitamin $\mathrm{E}$ depended mainly on the composition of the original milk. For vitamin A, it was partially influenced by both the original milk composition and the cheese-making process. Regarding folates and minerals, as well as total antioxidant capacity, the cheese composition varied mainly with the cheese-making process. In addition, the cheese-making technology had a significant effect on the cheese composition in minerals and folates, but did not influence the other components affected by the cheesemaking process. Consequently, the cheese contents of fat-soluble compounds depend directly on the conditions of milk production. On the contrary, the composition of cheese in water-soluble compounds varies independently of the conditions of milk production. The total antioxidant capacity of pressed cheeses, unlike the original milk, was positively correlated with some fat-soluble antioxidants. It could therefore be influenced by the conditions of milk production.
\end{abstract}

cheese-making process / milk composition / fatty acid / vitamin / mineral

摘要 - 干酪的营养品质: 牛奶组成和干酪加工工艺对干酪营养品质的影响。为了评定牛奶 的加工过程和干酪营养成分之间的关系，首先有必要了解干酪成分的变化在多大程度上取 决于原料奶的成分。因此本文采用 4 种在实际生产过程中经常使用的加工工艺, 系统地研 究了牛奶组成和干酪加工工艺对干酪营养成分的影响。由于原料奶的种类不同（如牛奶、 羊奶 ), 所以其营养成分差异较大。如果不考虑干酪的干物质, 则干酪中脂肪酸、 $\beta$-胡萝卜

* Corresponding author (通讯作者): jbc@clermont.inra.fr 
素、叶黄素和维生素 $\mathrm{E}$ 的含量与原料奶的原始组成含量密切相关。而维生素 $\mathrm{A}$ 的含量则受 原料奶组成和加工工艺的双重影响。研究结果认为手酪中叶酸、矿物质含量及总抗氧化能 力的变化主要取决于干酪的加工过程。干酪加工工艺对干酪中叶酸和矿物质的影响非常 大，但对其他成分没有影响。因此，干酪中脂溶性营养成分的变化与原料奶的生产密切相 关, 而水溶性营养成分的变化则与原料奶的生产条件无关。与原料奶不同, 干酪的抗氧化 能力与其中脂溶性抗氧化剂的含量呈正相关, 因此, 干酪抗氧化能力受牛奶生产条件的影响。

干酪加工工艺 / 牛奶的组成 / 脂肪酸 / 维生素 / 矿物质

Résumé - Effets respectifs de la composition du lait et de la transformation fromagère sur la variabilité de composition du fromage en composés d'intérêt nutritionnel. De façon à étudier la relation entre les conditions de production du lait et les teneurs en composés d'intérêt nutritionnel dans le fromage, il est nécessaire de savoir dans quelle mesure la variabilité de composition du fromage dépend de celle du lait d'origine. Les effets respectifs de la composition du lait et de la transformation fromagère sur la variabilité de composition du fromage en composés d'intérêt nutritionnel ont donc été étudiés en conditions réelles de production du fromage et en considérant quatre technologies fromagères différentes. Les caractéristiques nutritionnelles du lait à l'origine du fromage sont soumises à de grandes variations en partie dues à l'espèce animale (vache vs. chèvre). Mis à part les aspects liés à la teneur en matière sèche du fromage, la variabilité de composition du fromage en acides gras, en $\beta$-carotène, en xanthophylles et en vitamine $\mathrm{E}$ dépend principalement de la composition du lait d'origine, alors que pour la vitamine A celle-ci est influencée à la fois par la composition du lait d'origine et par la transformation fromagère. Par contre, la composition en folates et en minéraux du fromage, ainsi que son potentiel antioxydant total, varient principalement avec la transformation fromagère. Par ailleurs, le type de technologie fromagère exerce un effet important sur la composition du fromage en minéraux et en folates, mais n'a aucun effet sur les autres composés influencés par la transformation fromagère. En conséquence, la teneur du fromage en composés liposolubles, contrairement aux composés hydrosolubles, dépend directement des conditions de production du lait. Le potentiel antioxydant total des fromages à pâte pressée, à la différence de leur lait d'origine, est positivement corrélé avec certains composés antioxydants liposolubles. Il pourrait par conséquent être influencé par les conditions de production du lait.

transformation fromagère / composition du lait / acide gras / vitamine / minéraux

\section{INTRODUCTION}

The existence of a close relationship between diet composition and human health is now well-established. Besides the food safety aspects, the impact of diet on the risk of diseases depends on the different foods, and more particularly the macroand micronutrients of which they are composed. Within the Western diet, cheese represents a large part of the total milk product consumption, in particular in countries such as France, Greece and Italy [10] and in higher socioeconomic classes [70]. It is thus especially important to know the accurate nutritional composition of this milk product. While the macronutrient content of cheese is relatively wellknown and handled owing to its important role in organoleptic and technological properties [26], its fine composition in components of nutritional interest such as fatty acids, vitamins, minerals, trace elements and antioxidant compounds is much less documented. Moreover, since all the antioxidants work synergistically against the noxious effects of oxidative stress [75], the assessment of the total amount of electron-donating antioxidants in foods including cheese may be an interesting approach as a supplement to the measurement of individual dietary antioxidant contents.

Beyond the need to update food composition tables with reliable and representative data, the quantification of the relative influence of the different factors of cheese production, in particular those related to conditions of milk production, is essential in the perspective of predicting and handling 
the nutritional quality of cheese better. Indeed, the composition of the original milk from which cheese is manufactured can vary according to nutritional, genetic and physiological factors. For example, the nature of the animal's forage diet, i.e. botanical composition, maturity stage and preservation mode, strongly influences the milk composition in fatty acids, vitamins and carotenoids [13, 36]. Similarly, the nutritional composition of milk also depends on species, breed, parity, production yield and stage of lactation of the animals [33, 35, 36, 41]. The cheese composition in components of nutritional interest is therefore likely to depend on these different conditions of milk production.

To assess the relationship between conditions of milk production and cheese contents of components of nutritional interest, it is necessary to know precisely to what extent the compositional variability of cheese depends on that of milk. The cheese-making process can modify milk composition in a more or less important way depending on the manufacturing parameters, and thereby influence cheese composition. For example, the microbial fermentation that milk undergoes during its transformation into cheese can modulate cheese composition either directly by synthesizing B vitamins $[67,72]$ or indirectly by solubilizing certain minerals which may be lost into the whey following the milk coagulation and acidification of curd [53]. The influence of the cheese-making process on the cheese contents of other components such as carotenoids or fat-soluble vitamins are less well documented and need to be specified. Similarly, the importance of the manufacturing process in cheese composition compared with that of the conditions of milk production has not been quantified yet.

The aim of the present work was to determine the respective effects of milk composition and the cheese-making process on the cheese compositional variability in a large range of components of nutri- tional interest. This will allow the subsequent study of the relationship between the conditions of milk production and the nutritional composition of cheese.

\section{MATERIALS AND METHODS}

\subsection{Collection of milk and cheese samples from farms}

Five French farmhouse cheese varieties representing four types of cheese-making technology were studied: Abondance, Tomme de Savoie, Cantalet, Salers and Rocamadour. The main characteristics of these cheeses are described in Table I. Milk and cheese samples were obtained directly from farmhouse producers, except for Cantalet cheeses which were manufactured in an experimental dairy from milk collected in different farms. The collected samples were produced at two periods of the year, one-half in the winter period and the other in the summer period, among producers representing a wide range of conditions of milk production in order to promote large compositional variability [24, 36]. For Abondance, Tomme de Savoie and Rocamadour cheeses, milk samples were collected from 5 to 8 farmhouse producers in each period (Tab. I). As Salers cheese is produced only when cows are grazing, it was studied only in the summer period and milk samples were collected from 6 farmhouse producers. In the winter period, 12 cheeses of the Cantalet variety, for which the cheese-making process is very close to that of Salers cheese, were manufactured in an experimental dairy from milk collected from the tanks of 12 different farms.

Milk samples were taken from the cheese manufacture vat before the addition of starters, immediately stored at $+4{ }^{\circ} \mathrm{C}$ in plastic tubes, then transported in a coolbox to the laboratory where they were immediately aliquoted. Milk submitted for fat and protein analyses was preserved using a food preservative and stored at $+4{ }^{\circ} \mathrm{C}$ until analysis, while milk submitted for dry matter, 
Table I. Characteristics of the five cheese varieties studied.

\begin{tabular}{|c|c|c|c|c|c|}
\hline & Abondance & $\begin{array}{c}\text { Tomme de } \\
\text { Savoie }\end{array}$ & Cantalet & Salers & Rocamadour \\
\hline Production area & Alpes du Nord & Alpes du Nord & Massif Central & Massif Central & Massif Central \\
\hline $\begin{array}{l}\text { Official quality } \\
\operatorname{sign}^{1}\end{array}$ & PDO & PGI & PDO & PDO & PDO \\
\hline Milk nature & raw & raw & raw & raw & raw \\
\hline Species & cow & cow & cow & cow & goat \\
\hline $\begin{array}{l}\text { Cheese-making } \\
\text { technology }\end{array}$ & $\begin{array}{c}\text { pressed } \\
\text { semi-cooked }\end{array}$ & $\begin{array}{c}\text { pressed } \\
\text { uncooked }\end{array}$ & $\begin{array}{c}\text { pressed } \\
\text { uncooked }\end{array}$ & $\begin{array}{c}\text { pressed } \\
\text { uncooked }\end{array}$ & $\begin{array}{c}\text { lactic } \\
\text { coagulation }\end{array}$ \\
\hline Weight (kg) & $7-12$ & $1.2-2$ & $8-10$ & $38-48$ & 0.035 \\
\hline Diameter $(\mathrm{cm})$ & $38-43$ & $18-21$ & $20-22$ & $30-50$ & 6 \\
\hline Height (cm) & $7-8$ & $5-8$ & 30 & 45 & 1.6 \\
\hline Ripening time (d) & 120 & 40 & 150 & 150 & 7 \\
\hline Winter samples & 5 & 5 & 12 & 0 & 7 \\
\hline Summer samples & 5 & 5 & 0 & 6 & 8 \\
\hline
\end{tabular}

1 PDO: Protected Designation of Origin; PGI: Protected Geographical Indication.

fatty acid, vitamin, carotenoid, mineral and total antioxidant capacity analyses was aliquoted in plastic tubes, protected from light with aluminium foil and stored at $-20{ }^{\circ} \mathrm{C}$. The batches of cheese corresponding to each of the collected milk samples were marked and ripened, respectively, in an experimental cellar for Cantalet cheeses and in private cellars for the others. Subsequently, a representative sample of each cheese batch was taken at the end of the ripening period, immediately stored at $+4{ }^{\circ} \mathrm{C}$, and then transported in a coolbox to the laboratory. Cheeses were cut into slices representative of the whole cheese and the rind was removed since it is not usually consumed, except for Rocamadour cheeses. Cheese aliquots submitted for dry matter, fat, protein and salt analyses were stored at $+4{ }^{\circ} \mathrm{C}$ while those submitted for fatty acid, vitamin, carotenoid, mineral and total antioxidant capacity analyses were protected from light with aluminium foil and stored at $-20{ }^{\circ} \mathrm{C}$.

\subsection{Freeze-drying of milk and cheese samples}

Milk and cheese samples were freezedried in order to promote the long-term stability of the micronutrients [80] using a TS-12 lyophilizator (Froilabo, Meyzieu, France). For milk, a 3-mL aliquot of each sample was freeze-dried directly in a plastic tube for $48 \mathrm{~h}$ and then stored at $-20{ }^{\circ} \mathrm{C}$. About $200 \mathrm{~g}$ of each frozen cheese sample, corresponding to 2-3 slices for the Abondance, Tomme de Savoie, Cantalet and Salers varieties and to 5 whole cheeses for the Rocamadour variety, were cut into cubes and then freeze-dried for $72 \mathrm{~h}$. The samples were then crushed with a mixer and stored at $-20{ }^{\circ} \mathrm{C}$ in plastic tubes protected from light with aluminium foil.

\subsection{Determination of the gross composition of milk and cheese samples}

Dry matter (DM) of raw milk and freeze-dried cheese samples was measured 
by desiccation at $103{ }^{\circ} \mathrm{C}$ for $24 \mathrm{~h}$ [40]. Protein and fat contents of the milk were assessed by infrared spectroscopy (MilkoScan 4000, Foss Electric, Hilleröd, Denmark) and somatic cell counts using an automatic cell counter (Fossomatic 500, Foss Electric, Hilleröd, Denmark). Dry matter and fat of raw cheese samples were determined using the AFNOR method [2] and the Heiss butyrometric method [38], respectively. The sodium chloride content of cheeses was determined using a chloride analyzer (Model 926, Corning, Halstead, Essex, United Kingdom).

\subsection{Determination of the composition of milk and cheese samples in components of nutritional interest}

The fatty acid (FA) profile of lyophilized milk and cheese samples was determined by gas chromatography after FA transesterification into FA methyl ester using sodium methoxide as described by Loor et al. [51].

Carotenoids ( $\beta$-carotene, lutein and zeaxanthin), vitamin A (all-trans-retinol) and vitamin $\mathrm{E}$ ( $\alpha$-tocopherol) in raw milk and lyophilized cheese samples were analyzed using a method adapted from Lyan et al. [54]. Carotenoids and fat-soluble vitamins were extracted from samples after addition of echinenone (internal standard) by $2 \times 2$ volumes of hexane. The xanthophylls were separated from the hexane phase by adding $2 \times 2$ volumes of ethanol/ water solution $(90 / 10 ; \mathrm{v} / \mathrm{v})$. After evaporation of hexane the residue was saponified for $2 \mathrm{~h}$ at $37^{\circ} \mathrm{C}$ using $\mathrm{KOH}(10 \%$ in ethanol, w/v) containing pyrogallol. The nonsaponifiable fraction was then extracted with hexane and added to the residue of ethanol evaporation containing xanthophylls. After evaporation, the dry residue was finally redissolved in acetonitrile/dichloromethane mixture $(50 / 50 ; \mathrm{v} / \mathrm{v})$, and submitted for HPLC analysis.

Folates (vitamin B9) in raw milk and lyophilized cheese samples were extracted by performing a trienzyme treatment, adapted from Ndaw et al. [59]. Samples were treated simultaneously by pronase (E.C. 3.4.24.31) and $\alpha$-amylase (E.C. 3.2.1.1) (Sigma-Aldrich, Saint-Quentin-Fallavier, France) overnight in phosphate buffer containing ascorbic acid at $\mathrm{pH}$ 5.0. After heating at $100{ }^{\circ} \mathrm{C}$ for $5 \mathrm{~min}$, folates were deconjugated with chicken pancreas conjugase (Difco Laboratories, Detroit, MI, USA) at $\mathrm{pH} 7.0$ and $37^{\circ} \mathrm{C}$ for $3 \mathrm{~h}$. Enzyme blank preparations were also performed in order to subtract thereafter the amount of endogenous folates. The total folate content of the samples was determined as previously described by Christidès and Potier de Courcy [15] by a microbiological assay using Lactobacillus rhamnosus (ATCC 7469, Institut Pasteur, Paris, France).

Calcium $(\mathrm{Ca})$, magnesium $(\mathrm{Mg})$ and zinc ( $\mathrm{Zn})$ contents of raw milk and lyophilized cheese samples were determined by absorption atomic spectrophotometry, and potassium $(\mathrm{K})$ content by emission atomic spectrophotometry as described by Lopez et al. [52]. The phosphorus $(\mathrm{P})$ content of raw milk and lyophilized cheese samples was determined by a colorimetric method [1].

The total antioxidant capacity (TAC) of milk and cheese samples was assessed using the ferric reducing/antioxidant power (FRAP) assay modified from Benzie and Strain [5]. After appropriate dilutions, $200 \mu \mathrm{L}$ of diluted raw milk or lyophilized cheese samples were mixed with $1.8 \mathrm{~mL}$ of the ferrictripyridyltriazine (TPTZ) reagent (prepared by mixing $300 \mathrm{mmole} \cdot \mathrm{L}^{-1}$ acetate buffer, pH 3.6; 8 mmole $\cdot \mathrm{L}^{-1}$ 2, 4, 6-tripyridyl-5-triazine in $30 \mathrm{mmole} \cdot \mathrm{L}^{-1} \mathrm{HCl} ; 20 \mathrm{mmole} \cdot \mathrm{L}^{-1}$ $\mathrm{FeCl}_{3}$ in the ratio of $10: 1: 1$ ). The mixture was incubated at $37{ }^{\circ} \mathrm{C}$ for $10 \mathrm{~min}$, centrifuged and finally, the TPTZ complex formed with the reduced ferrous ions was measured on the supernatant at $593 \mathrm{~nm}$ in parallel with a blank sample using a Uvikon 941 plus series spectrophotometer (Kontron Instruments, Saint-Quentin-en-Yvelines, France). Results were calculated from a standard scale of ferrous sulfate ranging from 30 to $500 \mu \mathrm{mole} \cdot \mathrm{L}^{-1} \mathrm{Fe}^{2+}$ (SigmaAldrich, Saint-Quentin-Fallavier, France). 
Table II. Average gross composition of each type of cheese-making technology and corresponding original milk (mean $\pm \mathrm{SD})$.

\begin{tabular}{lcccc}
\hline & Abondance & Tomme de Savoie & Cantalet/Salers & Rocamadour \\
\hline & & \multicolumn{4}{c}{ Milk composition } \\
Dry matter $\left(\mathrm{g} \cdot \mathrm{L}^{-1}\right)$ & $127 \pm 4$ & $124 \pm 7$ & $127 \pm 7$ & $121 \pm 13$ \\
Protein $\left(\mathrm{g} \cdot \mathrm{L}^{-1}\right)$ & $33.0 \pm 1.9$ & $31.8 \pm 1.8$ & $30.8 \pm 1.8$ & $33.2 \pm 5.0$ \\
Fat $\left(\mathrm{g} \cdot \mathrm{L}^{-1}\right)$ & $38.8 \pm 4.2$ & $38.2 \pm 5.0$ & $37.7 \pm 3.3$ & $35.9 \pm 7.4$ \\
$\mathrm{SCC}\left(\times 10^{6} \cdot \mathrm{L}^{-1}\right)$ & $135 \pm 63$ & $157 \pm 116$ & $320 \pm 217$ & $2074 \pm 1325$ \\
& & Cheese composition & \\
Dry matter $\left(\mathrm{g} \cdot \mathrm{kg}^{-1}\right)$ & $636 \pm 19$ & $568 \pm 22$ & $624 \pm 13$ & $440 \pm 33$ \\
Fat $(\mathrm{g} \cdot \mathrm{kg}-1)$ & $334 \pm 21$ & $292 \pm 30$ & $324 \pm 15$ & $236 \pm 23$ \\
Salt $(\mathrm{g} \cdot \mathrm{kg}-1)$ & $15.4 \pm 3.9$ & $15.9 \pm 4.1$ & $24.5 \pm 7.6$ & $10.9 \pm 2.0$ \\
\hline
\end{tabular}

${ }^{1}$ Somatic cell counts.

\subsection{Statistical analysis}

The General Linear Model procedure of SAS 8.1 (SAS Institute Inc., Cary, NC, USA) was used. The effect of animal species on milk composition was quantified by performing one-way analysis of variance. In order to determine the respective effects of milk composition and the cheese-making process on the cheese compositional variability, an analysis of variance-covariance was done with a model including the cheesemaking technology and milk composition as covariates. Cheese-making technology was considered as a class variable and milk composition as a continuous variable. Least squares means are reported and differences were considered significant at the 5\% level. Duncan's multiple comparison test was used for pair comparisons of means. In order to study what parameters best determine the total antioxidant capacity of milk and cheese, correlation studies were undertaken between FRAP values and the other parameters.

\section{RESULTS AND DISCUSSION}

\subsection{Gross composition}

The gross composition of each type of cheese-making technology and corresponding original milk is shown in Table II. Average dry matter, protein and fat contents and somatic cell counts (SCC) of milk ranged from 121 to $127 \mathrm{~g} \cdot \mathrm{L}^{-1}, 30.8$ to $33.2 \mathrm{~g} \cdot \mathrm{L}^{-1}$, 35.9 to $38.8 \mathrm{~g} \cdot \mathrm{L}^{-1}$ and $135 \times 10^{6}$ to $2074 \times$ $10^{6}$ cells $\cdot \mathrm{L}^{-1}$, respectively, according to the corresponding cheese-making technology. Goat's milk, unlike cow's milk, exhibited high SCC, confirming the higher prevalence of high SCC in the bulk tank goat's milk as observed by Droke et al. [22].

Average dry matter, fat and salt contents of cheeses ranged from 440 to $636 \mathrm{~g} \cdot \mathrm{kg}^{-1}$, 236 to $334 \mathrm{~g} \cdot \mathrm{kg}^{-1}$ and 10.9 to $24.5 \mathrm{~g} \cdot \mathrm{kg}^{-1}$, respectively, according to the cheese-making technology. The pressed semi-cooked cheese and the lactic coagulation cheese had the highest and the lowest dry matter and fat contents, respectively. This is consistent with the whey draining applied in their respective making processes.

\subsection{Nutritional characteristics of milk}

The composition of milk in components of nutritional interest according to animal species (goat vs. cow) is shown in Table III. There was a high compositional variability among the selected samples for both goat's milk and cow's milk. For example, 
Table III. Effect of animal species on nutritional characteristics of milk.

\begin{tabular}{|c|c|c|c|c|c|c|c|}
\hline & \multicolumn{3}{|c|}{ Goat's milk } & \multicolumn{3}{|c|}{ Cow's milk } & \multirow[t]{2}{*}{$P^{1}$} \\
\hline & Min. & Mean \pm SD & Max. & Min. & Mean \pm SD & Max. & \\
\hline \multicolumn{8}{|l|}{$\begin{array}{l}\text { Fatty acids } \\
\left(\% \text { total } \mathrm{FA}^{2}\right)\end{array}$} \\
\hline $\mathrm{SFA}^{3}$ & 67.4 & $71.8 \pm 2.4$ & 77.8 & 56.9 & $68.2 \pm 5.0$ & 78.1 & $* *$ \\
\hline $\mathrm{C} 4: 0$ & 1.53 & $2.51 \pm 0.4$ & 3.23 & 3.22 & $3.74 \pm 0.3$ & 4.85 & $* * *$ \\
\hline C6:0 & 2.26 & $2.61 \pm 0.3$ & 3.23 & 1.60 & $2.29 \pm 0.2$ & 2.76 & $* * *$ \\
\hline C8:0 & 2.84 & $3.24 \pm 0.3$ & 3.84 & 0.87 & $1.42 \pm 0.2$ & 1.86 & $* * *$ \\
\hline C10:0 & 8.43 & $10.5 \pm 1.2$ & 12.5 & 1.63 & $3.01 \pm 0.6$ & 4.12 & $* * *$ \\
\hline $\mathrm{C} 12: 0$ & 3.33 & $4.98 \pm 1.0$ & 6.85 & 1.91 & $3.42 \pm 0.8$ & 5.06 & $* * *$ \\
\hline C14:0 & 8.76 & $11.0 \pm 1.1$ & 12.8 & 7.04 & $11.6 \pm 1.7$ & 14.6 & NS \\
\hline $\mathrm{C} 16: 0$ & 20.7 & $23.4 \pm 1.9$ & 26.4 & 21.8 & $29.0 \pm 3.6$ & 39.0 & $* * *$ \\
\hline C18:0 & 6.61 & $9.58 \pm 1.9$ & 14.0 & 5.94 & $9.54 \pm 1.8$ & 13.9 & NS \\
\hline MUFA $^{3}$ & 17.4 & $22.9 \pm 2.1$ & 27.2 & 18.7 & $27.0 \pm 4.1$ & 35.4 & $* * *$ \\
\hline $\mathrm{C} 18: 1 c 9$ & 13.1 & $18.2 \pm 1.9$ & 22.2 & 13.0 & $19.1 \pm 3.2$ & 25.3 & NS \\
\hline $\mathrm{C} 18: 1 t 11(+t 10)$ & 0.65 & $1.07 \pm 0.3$ & 1.97 & 0.96 & $1.92 \pm 1.0$ & 4.76 & $* * *$ \\
\hline PUFA $^{3}$ & 3.33 & $4.24 \pm 0.5$ & 5.08 & 2.54 & $3.87 \pm 1.0$ & 6.43 & NS \\
\hline $\mathrm{C} 18: 2 c 9 c 12$ & 1.47 & $2.28 \pm 0.4$ & 2.82 & 1.17 & $1.58 \pm 0.3$ & 2.18 & $* * *$ \\
\hline $\mathrm{C} 18: 2 c 9 t 11$ (CLA) & 0.36 & $0.50 \pm 0.1$ & 0.71 & 0.33 & $0.77 \pm 0.4$ & 1.77 & $* * *$ \\
\hline $\mathrm{C} 18: 3 c 9 c 12 c 15$ & 0.43 & $0.82 \pm 0.3$ & 1.39 & 0.33 & $0.74 \pm 0.3$ & 1.32 & NS \\
\hline \multicolumn{8}{|l|}{$\begin{array}{l}\text { Vitamins and } \\
\text { carotenoids }\end{array}$} \\
\hline$\beta$-carotene $\left(\mu \mathrm{g} \cdot \mathrm{L}^{-1}\right)$ & 0.00 & $0.00 \pm 0.0$ & 0.00 & 34.0 & $118 \pm 77$ & 290 & $* * *$ \\
\hline Xanthophylls $\left(\mu \mathrm{g} \cdot \mathrm{L}^{-1}\right)$ & 5.26 & $9.39 \pm 3.6$ & 15.9 & 5.16 & $14.2 \pm 8.2$ & 41.0 & $*$ \\
\hline Vitamin $A\left(\mu \mathrm{g} \cdot \mathrm{L}^{-1}\right)$ & 179 & $352 \pm 162$ & 760 & 128 & $323 \pm 138$ & 764 & NS \\
\hline Vitamin $E\left(\mu g \cdot L^{-1}\right)$ & 291 & $654 \pm 335$ & 1405 & 169 & $642 \pm 396$ & 1437 & NS \\
\hline Folates $\left(\mu \mathrm{g} \cdot \mathrm{L}^{-1}\right)$ & 33.4 & $94.8 \pm 46$ & 183 & 51.7 & $179 \pm 59$ & 347 & $* * *$ \\
\hline
\end{tabular}


Table III. Continued.

\begin{tabular}{|c|c|c|c|c|c|c|c|}
\hline & \multicolumn{3}{|c|}{ Goat's milk } & \multicolumn{3}{|c|}{ Cow's milk } & \multirow[t]{2}{*}{$P^{1}$} \\
\hline & Min. & Mean \pm SD & Max. & Min. & Mean $\pm \mathrm{SD}$ & Max. & \\
\hline \multicolumn{8}{|l|}{ Minerals } \\
\hline Calcium $\left(\mathrm{g} \cdot \mathrm{L}^{-1}\right)$ & 1.01 & $1.20 \pm 0.1$ & 1.42 & 1.07 & $1.22 \pm 0.1$ & 1.39 & NS \\
\hline $\begin{array}{l}\text { Phosphorus } \\
\left(\mathrm{g} \cdot \mathrm{L}^{-1}\right)\end{array}$ & 0.79 & $1.03 \pm 0.2$ & 1.38 & 0.83 & $0.94 \pm 0.1$ & 1.05 & $*$ \\
\hline $\begin{array}{l}\text { Potassium } \\
\left(\mathrm{g} \cdot \mathrm{L}^{-1}\right)\end{array}$ & 0.88 & $1.10 \pm 0.1$ & 1.26 & 0.94 & $1.06 \pm 0.1$ & 1.36 & NS \\
\hline $\begin{array}{l}\text { Magnesium } \\
\left(\mathrm{mg} \cdot \mathrm{L}^{-1}\right)\end{array}$ & 110 & $133 \pm 20$ & 161 & 87.8 & $98.1 \pm 6.5$ & 110 & $* * *$ \\
\hline $\operatorname{Zinc}\left(\mathrm{mg} \cdot \mathrm{L}^{-1}\right)$ & 2.92 & $3.95 \pm 0.9$ & 5.88 & 2.87 & $4.51 \pm 0.6$ & 6.00 & $*$ \\
\hline $\begin{array}{l}\mathrm{TAC}^{4} \\
\left(\mathrm{~mol} \mathrm{Fe}{ }^{2+} \cdot \mathrm{L}^{-1}\right)\end{array}$ & 1.30 & $2.63 \pm 0.7$ & 3.83 & 1.35 & $2.29 \pm 0.4$ & 3.14 & $*$ \\
\hline
\end{tabular}

${ }^{1}$ NS: not significant; $* P<0.05$; $* * P<0.01$; *** $P<0.001$.

2 Total FA: total fatty acids.

3 SFA: saturated fatty acids; MUFA: monounsaturated fatty acids; PUFA: polyunsaturated fatty acids.

4 Total antioxidant capacity.

C16:0, vitamin A and Ca ranged from 20.7 to $26.4 \%$ total FA, 179 to $760 \mu \mathrm{g} \cdot \mathrm{L}^{-1}$ and 1.01 to $1.42 \mathrm{~g} \cdot \mathrm{L}^{-1}$, respectively, in goat's milk. Similarly, they ranged from 21.8 to $39.0 \%$ total FA, 128 to $764 \mu \mathrm{g} \cdot \mathrm{L}^{-1}$ and 1.07 to $1.39 \mathrm{~g} \cdot \mathrm{L}^{-1}$, respectively, in cow's milk. This compositional variability therefore validates the relevance of the choice of the studied samples.

The animal species significantly influenced the composition of the milk (Tab. III). Goat's milk fat was on average significantly higher in caproic (C6:0), caprylic (C8:0), capric (C10:0), lauric (C12:0) and linoleic (cis-9 trans-12 C18:2) acids and lower in butyric (C4:0), palmitic (C16:0), vaccenic (trans-11 C18:1) and rumenic (cis-9 trans-11 C18:2) acids than cow's milk fat. Contrary to cow's milk, goat's milk was deprived of $\beta$-carotene, likely because of a higher enzymatic conversion of this carotenoid into retinal in the caprine intestine $[56,86]$, as also reflected by the presence of faint traces of this compound in the blood serum of the goat as compared with the cow [61]. Similarly, goat's milk was also poorer in xanthophylls and folates than cow's milk. Moreover, $\mathrm{P}$ and $\mathrm{Mg}$ contents were higher in goat's milk than in cow's milk, while the contrary was observed for $\mathrm{Zn}$ content. In addition, a higher total antioxidant capacity was measured in goat's milk. These results are in agreement with earlier reports $[14,35$, $41,74]$. They are, however, to be considered with caution insofar as the intra-species variability was higher than the interspecies variability for many parameters except for C4:0, C8:0, C10:0, $\beta$-carotene and $\mathrm{Mg}$, which markedly differed between the two animal species.

\subsection{Respective effects of milk composition and the cheese- making process on the nutritional compositional variability of cheese}

\subsubsection{Fatty acids}

The FA composition of cheese fat was subject to high variations. For instance, the cheese contents of palmitic and rumenic acids ranged, respectively, from 20.9 to 
36.7 and from 0.31 to $1.75 \%$ total FA (Fig. 1). Milk fat composition had a significant effect $(P<0.001)$ on the cheese fat compositional variability regarding all FA (Tab. IV). As illustrated in Figure 1, there was a very strong linear correlation $(P<0.001)$ between the cheese and milk FA profiles. The cheese fat compositional variability in FA depends therefore directly and almost exclusively on the milk fat composition $\left(r^{2}=\right.$ 0.70 to 0.99 ), suggesting that the cheesemaking process does not modify, or only very slightly modifies the compositional variability originally present in milk fat. On the other hand, apart from the aspects related to the fat content of cheese, the type of cheese-making technology had no significant effect on the cheese FA profile, except for C8:0 and C14:0 (Tab. IV). However, the influence of the type of cheesemaking technology was relatively low since for each one of the latter FA, it only contributed to $0.4 \%$ and $5.3 \%$ of the compositional variability in cheese fat, respectively.

Previous works devoted to the study of the effect of the cheese-making process on the FA composition of cheese were mainly focused on conjugated linoleic acid (CLA) $[29,32,34,42,48,73]$. As in the present work, Gnädig et al. [32] and Jiang et al. [42] found no effect of the manufacturing conditions on the CLA content of a French Emmental cheese and of two common types of Swedish hard cheeses, respectively. In contrast, in some cases weak positive or negative variations have been observed during the manufacture of Cheddar cheese [48] or processed cheese [29], which could be explained either by free-radical-type oxidation of linoleic acid, likely during aging and heat treatment [34], or by conversion of free linoleic acid into CLA by the dairy starter cultures $[43,48]$. However, although the ripening time, heating level and microflora composition varied between the different cheeses studied in the present work, the effect of these manufacturing parameters on the CLA content of cheese fat was negligible in comparison with that of the original milk composition.

\subsubsection{Fat-soluble vitamins and carotenoids}

Owing to the fat-soluble nature of vitamins $\mathrm{A}$ and $\mathrm{E}$ and carotenoids [18], it is necessary to normalize the values against fat in order to consider the respective effects of milk composition and the cheese-making process on the cheese compositional variability in these micronutrients. The $\beta$-carotene, xanthophylls, vitamin A and vitamin $E$ contents of cheese ranged from 0 to $7.30,0.06$ to $0.49,2.97$ to 10.8 and 1.30 to $12.9 \mathrm{mg} \cdot \mathrm{kg}^{-1}$ fat, respectively, as illustrated by the $\mathrm{Y}$-axis values in Figure 1 for $\beta$-carotene and vitamin $\mathrm{E}$.

The milk composition significantly affected $(P<0.001)$ the cheese composition in carotenoids and fat-soluble vitamins (Tab. IV). For each one of these components, there was a significant linear correlation $(P<0.001)$ between their level in cheese and milk fat. The compositional variability of cheese fat in $\beta$-carotene depended almost exclusively on that originally present in the milk fat $\left(r^{2}=0.96\right)$. However, it can be noted that the variations in xanthophylls, vitamin $\mathrm{A}$ and vitamin $\mathrm{E}$ contents in cheese fat were to a lesser extent explained by the milk fat composition $\left(r^{2}=0.72, r^{2}=0.54\right.$ and $r^{2}=0.81$, respectively). The cheese-making process therefore has a substantial effect on the vitamin $\mathrm{A}$, vitamin $\mathrm{E}$ and xanthophylls compositional variability in cheese fat, but in a way that is independent of the type of cheese-making technology, since this latter parameter did not significantly influence the cheese composition in these micronutrients apart from the aspects related to the fat content of the cheese (Tab. IV). In addition, only $5 \%$ of the $\beta$-carotene, but $34 \%$ of the vitamin A, $36 \%$ of xanthophylls and $67 \%$ of vitamin $\mathrm{E}$ originally present in milk fat were on average lost during the cheese-making process. For vitamin A, such a great loss is in agreement with the previous findings of Sabry and Guerrant [69] who observed a decrease in the initial total vitamin A content of milk fat, including 

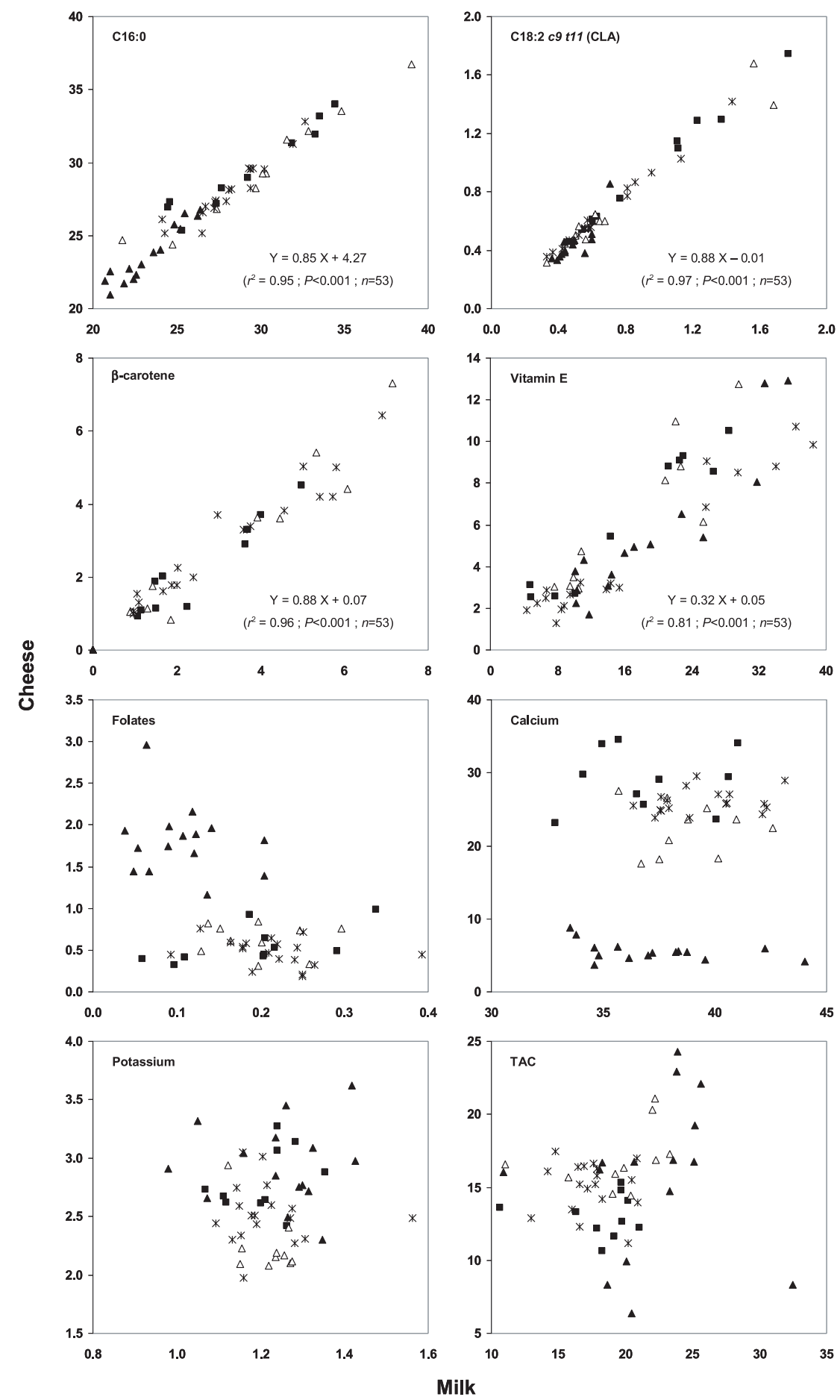
both retinol and $\beta$-carotene, ranging from $15 \%$ to $70 \%$ during the manufacture of three different cheeses. Similarly, it was already noted that the transfer of vitamin $\mathrm{E}$ from milk to cheese does not exceed $30 \%$ [36].

Regarding the loss of these fat-soluble micronutrients during the cheese-making process, several non-exclusive hypotheses can be put forward. Firstly, this loss may result from their oxidative degradation by atmospheric oxygen and light [20, 23], which is not controlled during the cheesemaking process. This chemical degradation may even be accelerated by increasing temperature and catalyzed by mineral ions, while acid conditions may facilitate both isomerization of all-trans-vitamin A to cis forms and de-esterification of vitamin $\mathrm{A}$ esters to more labile retinol [20, 23, 64, 78]. The high sensitivity of vitamins A and E to photoisomerization following light exposure of milk [21, 37, 58, 81] could particularly explain the loss of these compounds during cheese manufacturing. In addition, light exposure of cheese causes a marked destruction of vitamin A throughout the cheese and not only in the surface layer, although surface layer losses were always greater than inner losses [55]. Thus, the presence of isomers of all-trans-retinyl palmitate, known to result from light exposure $[30,87]$, in large amounts in cheese and not in milk $[62,76]$, confirms the instability of vitamin A during the cheese-making process. In contrast, the level of $\beta$-carotene and xanthophylls in milk would be little affected by light exposure [37]. The more significant loss of xanthophylls than of $\beta$-carotene during the cheese-making process may be explained by the higher stability of $\beta$-carotene against heat [77] associated with different behavior within lipid droplets. Indeed, within a biological emulsion as milk, the apolar carotenoid $\beta$-carotene would be solubilized almost exclusively in the lipid droplet core, while polar carotenoids with two hydroxyl groups such as lutein and zeaxanthin would distribute preferentially at the droplet surface [6]. Consequently, it is probable that in milk the microenvironment of these two types of carotenoids is different, which is known to influence the rate of carotenoid degradation [64].

Secondly, the decrease in these fat-soluble compounds during the cheese-making process could be due to a partial loss into the whey, in particular for vitamin A and xanthophylls. It has been shown that a significant percentage (about 10\%) of polar carotenoids (xanthophylls) localized at the lipid droplet surface could be spontaneously transferred to the aqueous phase without triglyceride lipolysis, while carotenoids localized in the droplet core absolutely require the production of water-soluble lipids to undergo such a transfer [6]. Similarly, the water solubility of vitamin A has been shown in the past [79], although the transfer of retinyl esters through an aqueous phase would be much slower because of their marked increased hydrophobicity [39]. In addition, the ability of the whey proteins, i.e. $\alpha$-lactalbumin and $\beta$-lactoglobulin, to form water-soluble complexes with retinol was demonstrated in several studies $[28,66]$. This may contribute to partial loss of vitamin A into the whey during the cheese-making process.

The non-significant effect of the cheesemaking technology on vitamin A and vitamin $\mathrm{E}$ contents of cheese in spite of differences of heating, acidification and

Figure 1. Relationship between cheese and milk composition in palmitic acid (C16:0), rumenic acid (C18:2 c9 t11), $\beta$-carotene, vitamin E, folates, calcium, potassium and total antioxidant activity (TAC). m: Abondance cheese; $\Delta$ : Tomme de Savoie cheese; $*$ : Cantalet/Salers cheeses and $\mathbf{\Delta}:$ Rocamadour cheese. Results are expressed as $\%$ total fatty acids for palmitic and rumenic acids, as $\mathrm{mg} \cdot \mathrm{kg}^{-1}$ fat for $\beta$-carotene and vitamin $\mathrm{E}$, as $\mathrm{mg} \cdot \mathrm{kg}^{-1}$ moisture for folates, as $\mathrm{g} \cdot \mathrm{kg}^{-1}$ defatted dry matter in cheese and as $\mathrm{g} \cdot \mathrm{kg}^{-1}$ protein in milk for calcium, as $\mathrm{g} \cdot \mathrm{kg}^{-1}$ moisture for potassium and as mol $\mathrm{Fe}^{2+} \cdot \mathrm{kg}^{-1}$ dry matter for TAC. 
Table IV. Effect of cheese-making technology and milk composition on the nutritional characteristics of cheese.

\begin{tabular}{|c|c|c|c|c|c|c|c|c|c|c|}
\hline & \multicolumn{4}{|c|}{ Cheese-making technology 1,2} & \multicolumn{3}{|c|}{$P^{3,4}$} & \multicolumn{3}{|c|}{ Partial R-square ${ }^{3}$} \\
\hline & A & $\mathrm{T}$ & CS & $\mathrm{R}$ & MC & $\mathrm{CT}$ & $\mathrm{MC} \times \mathrm{CT}$ & MC & CT & $\mathrm{MC} \times \mathrm{CT}$ \\
\hline \multicolumn{11}{|l|}{$\begin{array}{l}\text { Fatty acids } \\
\left(\% \text { total } \mathrm{FA}^{5}\right)\end{array}$} \\
\hline SFA $^{6}$ & 70.1 & 70.3 & 70.2 & 70.5 & $* * *$ & NS & NS & 0.892 & - & - \\
\hline $\mathrm{C} 4: 0$ & 3.68 & 4.13 & 4.00 & 3.40 & $* * *$ & NS & NS & 0.774 & - & - \\
\hline C6:0 & 2.55 & 2.75 & 2.63 & 2.64 & $* * *$ & NS & NS & 0.703 & - & - \\
\hline C8:0 & $2.33^{\mathrm{b}}$ & $2.13^{\mathrm{a}}$ & $2.04^{\mathrm{ab}}$ & $2.27^{\mathrm{ab}}$ & $* * *$ & $*$ & NS & 0.977 & 0.004 & - \\
\hline C10:0 & 6.07 & 5.51 & 5.19 & 5.57 & $* * *$ & NS & NS & 0.991 & - & - \\
\hline $\mathrm{C} 12: 0$ & 4.06 & 4.06 & 4.01 & 4.05 & $* * *$ & NS & NS & 0.888 & - & - \\
\hline $\mathrm{C} 14: 0$ & $12.2^{\mathrm{b}}$ & $12.1^{\mathrm{b}}$ & $11.7^{\mathrm{ab}}$ & $11.5^{\mathrm{a}}$ & $* * *$ & $* *$ & $* *$ & 0.728 & 0.053 & 0.056 \\
\hline C16:0 & 28.1 & 27.5 & 27.5 & 27.7 & $* * *$ & NS & NS & 0.951 & - & - \\
\hline C18:0 & 8.25 & 8.35 & 9.05 & 9.46 & $* * *$ & NS & NS & 0.718 & - & - \\
\hline MUFA $^{6}$ & 24.7 & 24.8 & 25.2 & 24.3 & $* * *$ & NS & NS & 0.882 & - & - \\
\hline $\mathrm{C} 18: 1 c 9$ & 17.8 & 17.8 & 18.5 & 17.3 & $* * *$ & NS & NS & 0.826 & - & - \\
\hline $\mathrm{C} 18: 1 t 11(+t 10)$ & 1.65 & 1.59 & 1.60 & 1.77 & $* * *$ & NS & NS & 0.844 & - & - \\
\hline PUFA $^{6}$ & 4.03 & 3.99 & 3.79 & 3.99 & $* * *$ & NS & NS & 0.895 & - & - \\
\hline $\mathrm{C} 18: 2 c 9 c 12$ & 1.74 & 1.77 & 1.75 & 1.86 & $* * *$ & NS & NS & 0.916 & - & - \\
\hline C18:2 c9t11 (CLA) & 0.69 & 0.66 & 0.67 & 0.67 & $* * *$ & NS & NS & 0.968 & - & - \\
\hline $\mathrm{C} 18: 3 c 9 c 12 c 15$ & 0.78 & 0.79 & 0.75 & 0.72 & $* * *$ & NS & NS & 0.917 & - & - \\
\hline \multicolumn{11}{|l|}{$\begin{array}{l}\text { Vitamins and } \\
\text { carotenoids }\end{array}$} \\
\hline $\begin{array}{l}\beta \text {-carotene } \\
\left(\mathrm{mg} \cdot \mathrm{kg}^{-1} \text { fat }\right)\end{array}$ & 1.97 & 1.98 & 2.17 & $n e^{7}$ & $* * *$ & NS & NS & 0.956 & - & - \\
\hline $\begin{array}{l}\text { Xanthophylls } \\
\left(\mathrm{mg} \cdot \mathrm{kg}^{-1} \text { fat }\right)\end{array}$ & 0.16 & 0.26 & 0.23 & 0.19 & $* * *$ & NS & NS & 0.723 & - & - \\
\hline $\begin{array}{l}\text { Vitamin A } \\
\left(\mathrm{mg} \cdot \mathrm{kg}^{-} \text {fat }\right)\end{array}$ & 5.09 & 5.29 & 4.96 & 5.82 & $* * *$ & NS & NS & 0.541 & - & - \\
\hline $\begin{array}{l}\text { Vitamin } E \\
\left(\mathrm{mg} \cdot \mathrm{kg}^{-1} \text { fat }\right)\end{array}$ & 5.67 & 5.67 & 5.07 & 5.71 & $* * *$ & NS & NS & 0.808 & - & - \\
\hline $\begin{array}{l}\text { Folates } \\
\left(\mathrm{mg} \cdot \mathrm{kg}^{-1} \text { moisture }\right)\end{array}$ & $0.53^{\mathrm{a}}$ & $0.63^{\mathrm{a}}$ & $0.50^{\mathrm{a}}$ & $1.67^{b}$ & NS & $* * *$ & NS & - & 0.828 & - \\
\hline
\end{tabular}


Table IV. Continued.

\begin{tabular}{|c|c|c|c|c|c|c|c|c|c|c|}
\hline & \multicolumn{4}{|c|}{ Cheese-making technology1,2 } & \multicolumn{3}{|c|}{$P^{3,4}$} & \multicolumn{3}{|c|}{ Partial R-square 3} \\
\hline & A & $\mathrm{T}$ & $\mathrm{CS}$ & $\mathrm{R}$ & MC & $\mathrm{CT}$ & $\mathrm{MC} \times \mathrm{CT}$ & MC & $\mathrm{CT}$ & $\mathrm{MC} \times \mathrm{CT}$ \\
\hline \multicolumn{11}{|l|}{ Minerals } \\
\hline $\begin{array}{l}\text { Calcium } \\
\left(\mathrm{g} \cdot \mathrm{kg}^{-1} \mathrm{DDM}^{5}\right)\end{array}$ & $29.3^{\mathrm{d}}$ & $22.4^{b}$ & $25.8^{\mathrm{c}}$ & $5.36^{\mathrm{a}}$ & NS & $* * *$ & NS & - & 0.931 & - \\
\hline $\begin{array}{l}\text { Phosphorus } \\
\left(\mathrm{g} \cdot \mathrm{kg}^{-1} \mathrm{DDM}^{5}\right)\end{array}$ & $17.9^{\mathrm{c}}$ & $16.8^{\mathrm{b}}$ & $16.7^{\mathrm{b}}$ & $10.5^{\mathrm{a}}$ & $* * *$ & $* * *$ & NS & 0.056 & 0.857 & - \\
\hline $\begin{array}{l}\text { Potassium } \\
\left(\mathrm{g} \cdot \mathrm{kg}^{-1} \text { moisture }\right)\end{array}$ & $2.81^{\mathrm{c}}$ & $2.24^{\mathrm{a}}$ & $2.52^{\mathrm{b}}$ & $2.94^{\mathrm{c}}$ & NS & $* * *$ & NS & - & 0.451 & - \\
\hline $\begin{array}{l}\text { Magnesium } \\
\left(\mathrm{g} \cdot \mathrm{kg}^{-1} \text { moisture }\right)\end{array}$ & $0.91^{\mathrm{c}}$ & $0.55^{\mathrm{b}}$ & $0.68^{\mathrm{b}}$ & $0.31^{\mathrm{a}}$ & NS & $* * *$ & NS & - & 0.859 & - \\
\hline $\begin{array}{l}\text { Zinc } \\
\left(\mathrm{mg} \cdot \mathrm{kg}^{-1} \mathrm{DDM}^{5}\right)\end{array}$ & $142^{\mathrm{c}}$ & $116^{\mathrm{b}}$ & $121^{\mathrm{b}}$ & $28.7^{\mathrm{a}}$ & NS & $* * *$ & NS & - & 0.926 & - \\
\hline $\begin{array}{l}\mathrm{TAC}^{8} \\
\left(\mathrm{~mol} \mathrm{Fe}^{2+} \cdot \mathrm{kg}^{-1} \mathrm{DM}^{5}\right)\end{array}$ & 13.0 & 17.0 & 14.6 & 15.6 & NS & NS & NS & - & - & - \\
\hline
\end{tabular}

$\overline{{ }^{1} \text { A: Abondance cheeses; T: Tomme de Savoie cheeses; CS: Cantalet and Salers cheeses; R: Rocamadour }}$ cheeses.

2 Values indicated are least-squares means adjusted for milk composition.

3 MC: milk composition effect; CT: cheese-making technology effect; MC $\times$ CT: statistical interaction between cheese-making technology and milk composition.

4 NS: not significant; $* P<0.05 ; * * P<0.01 ; * * *: P<0.001$.

5 Total FA: total fatty acids; DDM: defatted dry matter; DM: dry matter.

6 SFA: saturated fatty acids; MUFA: monounsaturated fatty acids; PUFA: polyunsaturated fatty acids.

7 Non estimated.

8 Total antioxidant capacity.

a, b, c, d Means within a row not sharing a common superscript differ significantly $(P<0.05)$.

ripening time can appear surprising. However, two studies have shown that the vitamin A content of milk decreased rapidly during the first hours of light exposure, but did not further decrease afterwards [21, 81]. Only a certain portion of the native vitamin A seems sensitive to light exposure. In addition, Poiffait et al. [65] have shown that casein is able to fix large quantities of retinol and $\alpha$-tocopherol, and retinol bound to casein resists better against degradation, in particular oxidation. It is thus possible that, whatever the type of cheese-making technology, a resistant portion of milk vitamin A, interacting possibly with caseins, would similarly be preserved in cheese.
Finally, authors have shown the ability of certain microorganisms to synthesize carotenoids [4]. Our results, however, suggest that such a synthesis, if any, does not appear to increase significantly the carotenoid content of the cheeses presently studied during their making process.

\subsubsection{Folates}

Folates are water-soluble vitamins [18]. In milk, they are bound to hydrophilic folate-binding protein (FBP) in a 1:1 stoichiometry [83]. In theory, folates have similar behavior to moisture during the cheese-making process. It is therefore necessary to normalize the values of folate 
content against moisture in the milk and cheese in order to estimate the respective effects of milk composition and the cheese-making process on the cheese compositional variability in this vitamin.

The folate content of cheese ranged between 0.19 and $2.96 \mathrm{mg} \cdot \mathrm{kg}^{-1}$ of moisture (Fig. 1). Such a compositional variability was not significantly influenced by the composition of the milk (Tab. IV). There was indeed no correlation between the folate contents of the cheese and milk for any cheese varieties studied, suggesting the strong influence of the cheese-making process. On the other hand, beyond the aspects related to the water content of cheese, the folate compositional variability of the cheese was explained in great part $\left(r^{2}=0.83\right)$ by a significant effect $(P<$ $0.001)$ of the type of cheese-making technology (Tab. IV). The Rocamadour cheese was about three times richer in folates than the other cheeses studied. These results agree with previous studies showing large variations in B vitamin contents between different cheese varieties [45, 71, 72]. In addition, the moisture of the cheeses presently studied was richer in folates than the moisture of the milk (Fig. 1), indicating that a portion of folates interacted with the cheese dry matter and/or microbial synthesis occurred during the cheese manufacturing. This could be particularly significant in the case of Rocamadour cheese which exhibited a very high content of folates.

The combination of microbial synthesis and morphological differences was most probably responsible in great part for the differences in folate content between the cheese varieties. Microbial synthesis of B vitamins in cheese has been reported by different studies $[67,69,72]$. The ability of microorganisms to synthesize $\mathrm{B}$ vitamins greatly varies according to the microbial species and strains [19, 46, 49]. Physicochemical conditions $(\mathrm{pH}$, temperature, water activity and oxygen content) are basic to microbial selection and thereby may influence the B vitamin content of cheese.
This is illustrated by the work of Shahani et al. [72] who, using the same lot of milk for cheese-making, found a level of microbial synthesis during the ripening more or less significant according to the type of cheese-making technology. In addition, the microbial $\mathrm{B}$ vitamin synthesis is higher in the outer layers than in the core of the cheese, owing to significant $B$ vitamin synthesis by the surface microflora [45]. Consequently, the proportionally larger outer layers of Rocamadour cheese, owing to its smaller size as well as the fact that this cheese variety is consumed entirely while the rind of the other cheeses is usually removed before consumption, probably strongly contribute to the higher level of folates in Rocamadour cheese as compared with the others.

The differences in folate content between the cheese varieties could also, to a lesser extent, result from a higher level of retention of the folates in Rocamadour cheese. Two non-exclusive hypotheses can be put forward to explain such a phenomenon. Firstly, it is possible that folates behave differently in milk according to the animal species, resulting in a higher proportion of folates in bound form in goat's milk than in cow's milk. Secondly, Collins and Yaguchi [17] showed that rennet-induced coagulation of milk released a higher proportion of vitamin B12, and possibly folates, bound to protein than acid coagulation. Acid coagulation of milk is used in the Rocamadour cheese-making process, whereas the other cheese varieties presently studied are manufactured using rennet coagulation. The proportion of folates lost into the whey could therefore be lower in the manufacture of Rocamadour cheese as compared with the other cheese varieties. However, although the results of Jones et al. [44] indicated that casein may interact with FBP, with the free folates or with both, the richness in FBP and folates of the whey from Cottage cheese manufacturing and the poverty in FBP of hard cheeses measured by Wigertz et al. [84] suggest that the portion of native folates 
interacting with casein during the cheesemaking is low.

\subsubsection{Minerals}

In milk, minerals are either in water-soluble form or in insoluble colloidal form bound to casein [3]. The respective proportions of the different mineral forms depend on the component considered. In cow's milk, $\mathrm{Ca}, \mathrm{P}$ and $\mathrm{Zn}$ are mainly in caseinbound form (about 75, 60 and 98\%, respectively) while $\mathrm{Mg}$ and $\mathrm{K}$ are mainly in soluble form (about 70 and 90\%, respectively) $[8,9,25,47]$. According to their dominant form in milk, minerals can therefore behave either as moisture or as casein during the cheese-making process. For this reason, it is necessary to normalize the values either against moisture for $\mathrm{Mg}$ and $\mathrm{K}$ or against protein for $\mathrm{Ca}, \mathrm{P}$ and $\mathrm{Zn}$ in milk and cheese in order to consider the respective effects of milk composition and the cheese-making process on the cheese compositional variability in these mineral elements.

The mineral contents of the cheese ranged from 3.65 to $34.4 \mathrm{~g} \cdot \mathrm{kg}^{-1}$ of defatted dry matter (DDM), 9.21 to $19.0 \mathrm{~g} \cdot \mathrm{kg}^{-1}$ DDM and 21.5 to $164.5 \mathrm{mg} \cdot \mathrm{kg}^{-1}$ DDM for $\mathrm{Ca}, \mathrm{P}$ and $\mathrm{Zn}$, respectively, and from 1.97 to $3.62 \mathrm{~g} \cdot \mathrm{kg}^{-1}$ of moisture and 0.22 to $1.21 \mathrm{~g} \cdot \mathrm{kg}^{-1}$ of moisture for $\mathrm{K}$ and $\mathrm{Mg}$, respectively. The mineral compositional variability did not significantly depend on that of the original milk, except for $\mathrm{P}$ (Tab. IV). However, only $5.6 \%$ of the cheese compositional variability in this mineral was explained by the milk composition. As a consequence, no significant correlation between the cheese and milk composition was observed as illustrated for $\mathrm{Ca}$ and $\mathrm{K}$ in Figure 1. In other terms, the mineral compositional variability of cheese depends almost exclusively on the cheese-making process.

On the other hand, there was a significant effect $(P<0.001)$ of the type of cheese-making technology on the mineral contents of cheese beyond the aspects related to the protein or water contents of cheese (Tab. IV). The Abondance pressed semi-cooked cheese and the Rocamadour lactic coagulation cheese had the highest and the lowest levels of $\mathrm{Ca}, \mathrm{P}, \mathrm{Mg}$ and $\mathrm{Zn}$, respectively, while the pressed uncooked cheeses were characterized by intermediate contents. These results agree with previous studies [16, 27, 57, 85]. These differences in mineral composition between the cheeses can be related to differences in acidification, heating and salting levels $[47,53]$. As a result of milk fermentation, the decrease in milk $\mathrm{pH}$ renders progressively soluble colloidal calcium phosphate, Ca bound to phosphoserines and carboxyls as well as $\mathrm{Mg}$ bound to casein [7, 9, 47]. In cow's milk, the inorganic $\mathrm{P}$ is completely solubilized at pH 5.2, while complete solubilization of $\mathrm{Ca}$ and $\mathrm{Mg}$ is obtained only after acidification at $\mathrm{pH} 3.5$ [47]. Consequently, the higher the milk acidification level before draining, the higher the proportion of minerals lost into the whey. Among the cheese varieties presently studied, the Abondance pressed semi-cooked cheese and the Rocamadour lactic coagulation cheese are characterized by the lowest and the highest level of acidification before draining, respectively. This explains in great part why these cheeses were the richest and the poorest in $\mathrm{Ca}, \mathrm{P}, \mathrm{Mg}$ and $\mathrm{Zn}$, respectively, these compounds occurring significantly in insoluble colloidal form in milk $[8,9,25]$. In addition, the higher the temperature, the higher the amount of $\mathrm{Ca}$ bound to casein $[7,63]$. The lower renneting and maturation temperatures in the cheesemaking process of the Rocamadour cheese $\left(12-20^{\circ} \mathrm{C}\right)$ compared with those of the pressed cheeses presently studied (30$34{ }^{\circ} \mathrm{C}$ ) could therefore increase the differences of $\mathrm{Ca}$ solubilization before draining caused by acidification. On the contrary, the increase in ionic strength due to addition of sodium chloride leading to a higher solubilization of $\mathrm{Ca}$ and $\mathrm{Mg}$ but not of $\mathrm{P}[7$, $47,63]$, the higher level of salting in the manufacturing of the pressed cheeses compared with that of the Rocamadour cheese could attenuate the differences in 
demineralization induced by different levels of acidification before draining. The importance of this latter factor in the mineral composition of cheese seems, however, relatively low with regard to the respective mineral solubilization levels in the cheeses presently studied. Indeed, the proportions of $\mathrm{Ca}, \mathrm{P}, \mathrm{Mg}$ and $\mathrm{Zn}$ in soluble form were, respectively, estimated at 22.2, 54.3, 67.8 and $0.0 \%$ in Abondance cheese, i.e. very similar to the original milk, versus 94.5 , $79.2,88.2$ and $84.1 \%$ in Rocamadour cheese, while they were intermediate in the uncooked pressed cheeses $(40.1,60.4,76.6$ and $18.2 \%$, respectively).

As regards the $\mathrm{K}$ content, the Abondance pressed semi-cooked cheese and the Rocamadour lactic coagulation cheese were richer than the uncooked pressed cheeses (Tab. IV). The differences within the cow's milk cheeses resulted almost only from differences in dry matter owing to the proportion of $\mathrm{K}$ interacting with casein. The proportion of $\mathrm{K}$ in soluble form was estimated at 93.7 and $94.9 \%$ in the Abondance and the pressed uncooked cheeses, respectively, showing similar levels of solubilization. On the other hand, in spite of a higher acidification level before draining, the Rocamadour cheese was not the poorest in $\mathrm{K}$, contrary to other mineral elements. This could be specific to the caprine nature of this cheese variety. A larger proportion of $\mathrm{K}$ could be in insoluble form in goat's milk compared with cow's milk, thus reducing its loss into the whey, considering that a complete solubilization of $\mathrm{K}$ is obtained only after acidification at pH 4.2 [47]. The lower estimated proportion of $\mathrm{K}$ in soluble form in Rocamadour cheese than in the cow's milk cheeses $(84.7 \%$ vs. $93.7-94.9 \%)$ is in agreement with this hypothesis.

\subsubsection{Total antioxidant capacity}

The TAC of cheeses ranged from 6.35 to $24.3 \mathrm{~mol} \mathrm{Fe}{ }^{2+} \cdot \mathrm{kg}^{-1} \mathrm{DM}$ (Fig. 1). Neither the milk composition nor the cheese-making technology were significantly corre- lated with the TAC (Tab. IV). The TAC variability between the cheeses was therefore mainly influenced by the cheese-making process but independently of the type of cheese-making technology. Several compounds in milk are known to be antioxidant such as $\beta$-carotene, $\alpha$-tocopherol, ascorbic acid, uric acid, whey proteins and caseins $[11,50,60,82]$. Among these compounds, some have a high ferric-reducing ability, e.g. $\alpha$-tocopherol, ascorbic acid, uric acid, and others a low one, e.g. whey proteins [5, 12]. None of the antioxidant compounds analyzed in this study was found to be positively or negatively correlated with the TAC either in goat's milk or cow's milk. This may be explained either by a combined influence of many compounds varying independently from each other or by variations in the content of compounds not analyzed in this work such as uric acid, ascorbic acid or whey proteins.

The cheese-making process caused both a decrease in the TAC of the milk (Fig. 1), since the TAC of the milk was higher than the TAC of the cheese (19.3 vs. $15.2 \mathrm{~mol}$ $\left.\mathrm{Fe}^{2+} \cdot \mathrm{kg}^{-1} \mathrm{DM}\right)$, and the appearance of many associations which were not present in the milk, as illustrated for some of the analyzed compounds in Figure 2. That was probably the result of a loss of uric acid, known to account for a great proportion of the ferric-reducing activity of whey [12], and, to a lesser extent, other water-soluble antioxidant compounds such as ascorbic acid and whey proteins during the cheesemaking process. On the other hand, microbial activity could cause an increase in other compounds (e.g. B vitamins) therefore having a higher effect on the TAC in cheese than in milk. As a result, the TAC variability in the Abondance and Cantalet/ Salers cheeses was directly dependent on the variations in antioxidant compounds that are little influenced by the cheesemaking process such as $\beta$-carotene $(r=$ $0.72)$ and vitamin $\mathrm{E}(r=0.79)$ for Abondance cheese and $\beta$-carotene $(r=0.55)$ for Cantalet/Salers cheeses (Fig. 2). Similarly, in Rocamadour cheese the TAC was positively 


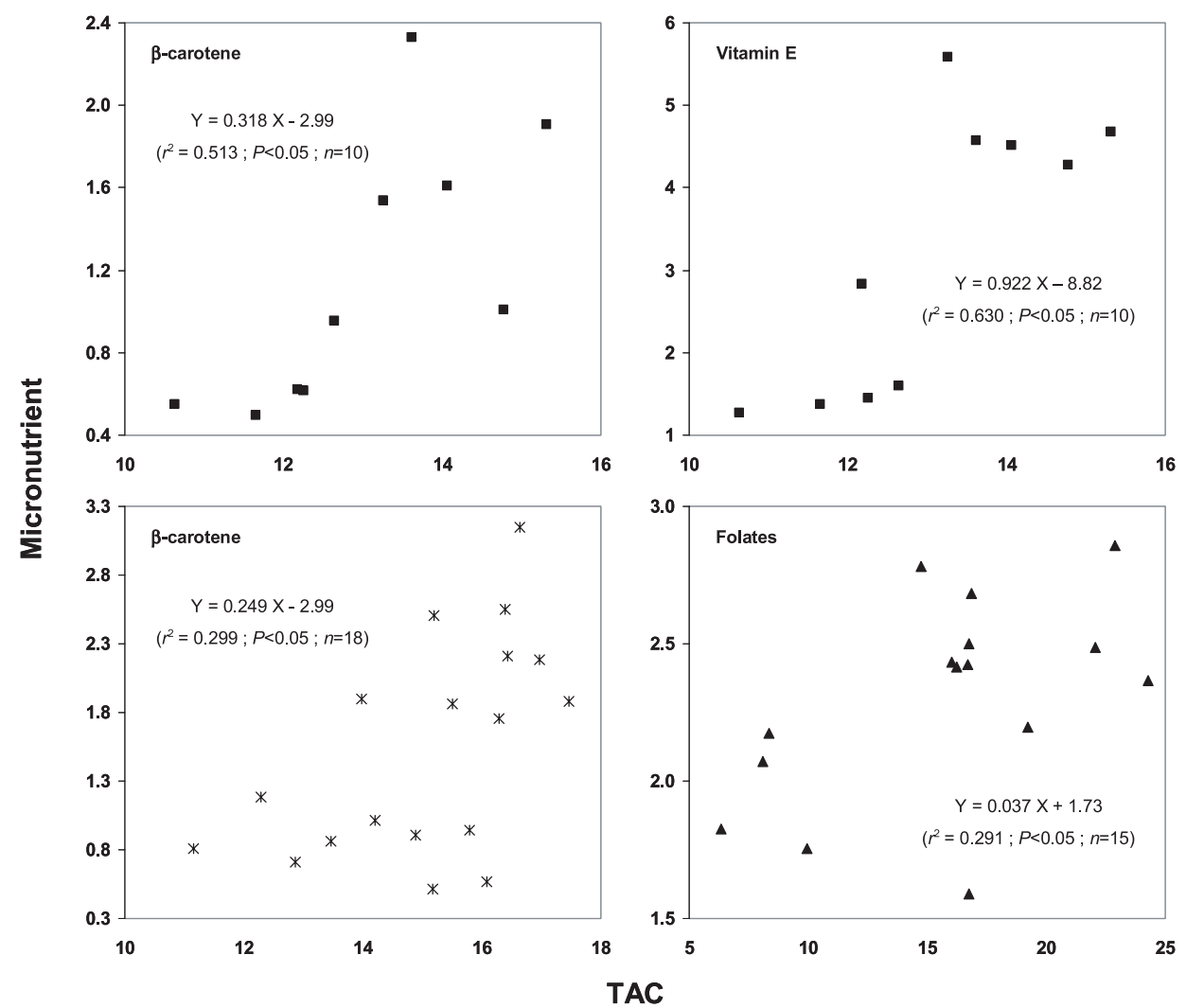

Figure 2. Relationship between total antioxidant activity (TAC) and some micronutrients in cheese. a: Abondance cheese; $*$ : Cantalet/Salers cheeses and $\mathbf{\Delta}$ : Rocamadour cheese. Results are expressed as mol $\mathrm{Fe}^{2+} \cdot \mathrm{kg}^{-1}$ dry matter for TAC and as $\mathrm{mg} \cdot \mathrm{kg}^{-1}$ dry matter for $\beta$-carotene, vitamin $\mathrm{E}$ and folates.

associated with folate content $(r=0.54$; Fig. 2), known to be antioxidant [68] and able to reduce $\mathrm{Fe}^{3+}$ to $\mathrm{Fe}^{2+}[31]$. However, since folates originate in great proportion from microbial synthesis in Rocamadour cheese, their positive association with the TAC may also indicate a significant microbial influence on the ferric-reducing ability of this cheese. In addition, the TAC was also correlated positively with PUFA $(r=$ $0.75)$ and negatively with SFA $(r=-0.75)$ in Abondance cheese. FA that are not antioxidant per se might be indirectly associated with the TAC of cheese because of primary correlation with other antioxidant compounds. For example, there was a neg- ative correlation between SFA and $\beta$-carotene $(r=-0.78)$ and vitamin $\mathrm{E}(r=-0.95)$ in Abondance cheese. On the other hand, the TAC in Tomme de Savoie cheese was not significantly associated with any of the analyzed compounds.

\section{CONCLUSION}

The nutritional characteristics of milk are subject to high variations which are partly due to animal species. However, it can also be modified to some extent by the cheese-making process but in a way more or less significant according to the nutrient. 
Apart from the aspects related to the dry matter content of cheese, the cheese compositional variability in FA, $\beta$-carotene, xanthophylls and vitamin $\mathrm{E}$ depends mainly on the compositional variability of the original milk. That in vitamin A is influenced by milk compositional variability and the cheese-making process to a similar extent, while that in folates, minerals $(\mathrm{Ca}$, $\mathrm{P}, \mathrm{Mg}, \mathrm{K}$ and $\mathrm{Zn}$ ) and total antioxidant capacity is mainly determined by the cheese-making process. Moreover, the type of cheese-making technology has an important effect on the cheese composition in minerals and folates, but does not significantly influence the other components affected by the cheese-making process.

Consequently, the cheese compositional variability in fat-soluble components (FA, carotenoids, and vitamins $\mathrm{A}$ and $\mathrm{E}$ ), but not in water-soluble components (folates and minerals), can be directly explained by the conditions of milk production. Although it was not the case for milk, the total antioxidant capacity of cheese was significantly correlated with fat-soluble antioxidants in pressed cheeses, suggesting it may also depend on the conditions of milk production. Future studies will be designed to investigate further the relationship existing between the conditions of milk production and the nutritional characteristics of cheese made from goat's milk or cow's milk.

Acknowledgements: This work was carried out within the framework of the programs of research and development of Groupement d'Intérêt Scientifique des Alpes du Nord (Chambéry, France) and Pôle Fromager AOC Massif Central (Aurillac, France). We thank the Comité Interprofessionnel des Fromages du Cantal (Aurillac, France), Syndicat Interprofessionnel du Fromage d'Abondance (Thonon-lesBains, France), Syndicat Interprofessionnel de la Tomme de Savoie (Annecy, France) and Syndicat des Producteurs du Fromage Rocamadour (Cahors, France) for their contribution to this study. The authors thank the Association National de la Recherche Technique for financial support. We are grateful to R. Lavigne from the Unité de Recherches Fromagères (INRA, Aurillac, France), Dr. G. Potier de Courcy from the Institut Scientifique et Technique de la Nutrition et de l'Alimentation (Paris, France), P. Capitan from the Unité de Recherches sur les Herbivores (INRA, Clermont-Ferrand, France), and B. Lyan, J.-C. Tressol and C. Lab from the Unité de Maladies Métaboliques et de Micronutriments (INRA, Clermont-Ferrand, France) for technical assistance with manufacturing Cantalet cheeses, the microbiological assay used to determine folate content, determination of fatty acid profiles, fat-soluble vitamin and carotenoid analysis, mineral analysis and the total antioxidant capacity assay, respectively. We also acknowledge B. Martin and A. Ferlay from the Unité de Recherches sur les Herbivores for their critical and helpful suggestions.

\section{REFERENCES}

[1] AFNOR, Fromage. Détermination de la teneur en phosphate total. Méthode par spectrométrie d'absorption moléculaire. Norme NF V04-284 (1985).

[2] AFNOR, Fromage. Détermination de la matière sèche (méthode par étuvage). Norme NF V04-282 (1980).

[3] Alais A., Les matières minérales. Les acides organiques, in: Science du lait. Principes des techniques laitières, Sepaic, Paris, France, 1984, pp. 201-221.

[4] Baumann C.A., Steenbock H., Ingraham M.A., Fred E.B., Fat-soluble vitamins. XXXVII. Microorganisms and the synthesis of carotene and vitamin A, J. Biol. Chem. 103 (1933) 339-351.

[5] Benzie I.F.F., Strain J.J., The ferric reducing ability of plasma (FRAP) as a measure of "antioxidant power": the FRAP assay, Anal. Biochem. 239 (1996) 70-76.

[6] Borel P., Grolier P., Armand M., Partier A., Lafont H., Lairon D., Azais-Braesco V., Carotenoids in biological emulsions: solubility, surface-to-core distribution, and release from lipid droplets, J. Lipid Res. 37 (1996) 250-261.

[7] Brulé G., Fauquant J., Mineral balance in skim-milk and milk retentate: effect of physicochemical characteristics of the aqueous phase, J. Dairy Res. 48 (1981) 91-97.

[8] Brulé G., Fauquant J., Interactions between milk proteins and trace elements, Lait 62 (1982) 323-331.

[9] Brulé G., Maubois J.L., Fauquant J., Étude de la teneur en éléments minéraux des produits obtenus lors de l'ultrafiltration du lait sur membrane, Lait 539-540 (1974) 600-615. 
[10] Centre National Interprofessionnel de l'Économie Laitière, Banque de données statistiques, http://www.cniel.com/scripts/public/ stat.asp.

[11] Cervato G., Cazzola R., Cestaro B., Studies on the antioxidant activity of milk caseins, Int. J. Food Sci. Nutr. 50 (1999) 291-296.

[12] Chen J., Lindmark-Månsson H., Gorton L., Akesson B., Antioxidant capacity of bovine milk as assayed by spectrophotometric and amperometric methods, Int. Dairy J. 13 (2003) 927-935.

[13] Chilliard Y., Ferlay A., Doreau M., Effect of different types of forages, animal fat or marine oils in cow's diet on milk fat secretion and composition, especially conjugated linoleic acid (CLA) and polyunsaturated fatty acids, Livest. Prod. Sci. 70 (2001) 31-48.

[14] Chilliard Y., Ferlay A., Rouel J., Lamberet G., A review of nutritional and physiological factors affecting goat milk lipid synthesis and lipolysis, J. Dairy Sci. 86 (2003) 1751-1770.

[15] Christidès J.P., Potier de Courcy G., Teneur en acide folique des aliments. 2. Optimisation du dosage microbiologique des folates dans les aliments, Sci. Aliments 7 (1987) 7-22.

[16] Cichoski A.J., Valduga E., Valduga A.T., Tornadijo M.E., Fresno J.M., Characterization of Prato cheese, a Brazilian semi-hard cow variety: evolution of physico-chemical parameters and mineral composition during ripening, Food Control 13 (2002) 329-336.

[17] Collins E.B., Yaguchi M., Vitamin $B_{12}$ in wheys prepared by coagulating milk with acid and rennet, J. Dairy Sci. 42 (1959) 19271931.

[18] Cooper D.A., Webb D.R., Peters J.C., Evaluation of the potential for olestra to affect the availability of dietary phytochemicals, J. Nutr. 127 (1997) 1699S-1709S.

[19] Crittenden R.G., Martinez N.R., Playne M.J., Synthesis and utilisation of folate by yoghurt starter cultures and probiotic bacteria, Int. J. Food Microbiol. 80 (2003) 217-222.

[20] De Ritter E., Stability characteristics of vitamins in processed foods, Food Technol. 30 (1976) 48-54.

[21] De Man J.M., Light-induced destruction of vitamin A in milk, J. Dairy Sci. 64 (1981) 2031-2032.

[22] Droke E.A., Paape M.J., Di Carlo A.L., Prevalence of high somatic cell counts in bulk tank goat milk, J. Dairy Sci. 76 (1993) 10351039.

[23] Erdman J.W., Poor C.L., Dietz J.M., Factors affecting the bioavailability of vitamin A, carotenoids, and vitamin E, Food Technol. 42 (1988) 214-221.
[24] Faulkner A., Brechany E.Y., Mabon R.M., Pollock H.T., Seasonal changes in the fat composition and concentration of citrate and related metabolites in cows' milk, J. Dairy Res. 53 (1986) 223-227.

[25] Fischbach-Greene L., Potter N.N., Effects of ultrafiltration on retention of minerals and other components of milk, J. Food Sci. 51 (1986) 345-347.

[26] Fox P.F., Cheese: chemistry, physics and microbiology, Vol. 2, General aspects, Chapman \& Hall, London, UK, 1993.

[27] Fresno J.M., Tornadijo M.E., Carballo J., González-Prieto J., Bernardo A., Characterization and biochemical changes during the ripening of a Spanish craft goat's milk cheese (Armada variety), Food Chem. 55 (1996) 225-230.

[28] Futterman S., Heller J., The enhancement of fluorescence and the decreased susceptibility to enzymatic oxidation of retinol complexed with bovine serum albumin, beta-lactoglobulin, and the retinol-binding protein of human plasma, J. Biol. Chem. 247 (1972) 51685172.

[29] Garcia-Lopez S., Echeverria E., Tsui I., Balch B., Changes in the content of conjugated linoleic acid (CLA) in processed cheese during processing, Food Res. Int. 27 (1994) 61-64.

[30] Gaylord A.M., Warthesen J.J., Smith D.E., Effect of fluorescent light on the isomerization of retinyl palmitate in skim milk, J. Food Sci. 51 (1986) 1456-1458.

[31] Gliszczyńska-Swiglo A., Antioxidant activity of water soluble vitamins in the TEAC (trolox equivalent antioxidant capacity) and the FRAP (ferric reducing antioxidant power) assays, Food Chem. 96 (2006) 131-136.

[32] Gnädig S., Chamba J.F., Perreard E., Chappaz S., Chardigny J.M., Rickert R., Steinhart H., Sébédio J.L., Influence of manufacturing conditions on the conjugated linoleic acid content and the isomer composition in ripened French Emmental cheese, J. Dairy Res. 71 (2004) 367-371.

[33] Guéguen L., La composition minérale du lait et son adaptation aux besoins minéraux du jeune, Ann. Nutr. Alim. 24 (1971) A335A381.

[34] Ha Y.L., Grimm N.K., Pariza M.W., Newly recognized anticarcinogenic fatty acids: identification and quantification in natural processed cheeses, J. Agric. Food Chem. 37 (1989) 75-81.

[35] Haenlein G.F.W., Past, present, and future perspectives of small ruminant dairy research, J. Dairy Sci. 84 (2001) 2097-2115. 
[36] Hartman A.M., Dryden L.P., Vitamins in milk and milk products, American Dairy Science Association, USA, 1965.

[37] Havenose M.S., Riis Weisbjerg M., Bredie W.L.P., Nielsen J.H., Influence of feeding different types of roughage on the oxidative stability of milk, Int. Dairy J. 14 (2004) 563570 .

[38] Heiss E., Essai de dosage de la matière grasse dans les fromages par des méthodes rapides, Dtsch. Molk. Zeit. 82 (1961) 67-70.

[39] Ho M.T., Massey J.B., Pownall H.J., Anderson R.E., Hollyfield J.G., Mechanism of vitamin A movement between rod outer segments, interphotoreceptor retinoid-binding protein, and liposomes, J. Biol. Chem. 264 (1989) 928-935.

[40] IDF, Determination of the total solids contents: gravimetric (cheese and processed cheese), Standard 4A, International Dairy Federation, Brussels, Belgium, 1982.

[41] Jenness R., Composition and characteristics of goat milk: review 1968-1979, J. Dairy Sci. 63 (1980) 1605-1630.

[42] Jiang J., Björck L., Fondén R., Conjugated linoleic acid in Swedish dairy products with special reference to the manufacture of hard cheeses, Int. Dairy J. 7 (1997) 863-867.

[43] Jiang J., Björck L., Fondén R., Production of conjugated linoleic acid by dairy starter cultures, J. Appl. Microbiol. 85 (1998) 95-102.

[44] Jones M.L., Treloar T., Nixon P.F., Dietary interactions influence the effects of bovine folate-binding protein on the bioavailability of tetrahydrofolates in rats, J. Nutr. 133 (2003) 489-495.

[45] Karlin R., Sur l'acide folique dans le fromage de consommation courante, Ann. Nutr. Alim. 12 (1958) 115-120.

[46] Karlin R., Sur l'évolution de la teneur en vitamine $\mathrm{B}_{12}$ des laits fermentés: possibilités d'enrichissement par adjonction aux associations microbiennes du Propionibacterium shermanii, Ann. Nutr. Alim. 15 (1961) 247256.

[47] Le Graët Y., Brulé G., Effects of pH and ionic strength on mineral balance of milk, Lait 73 (1993) 57-60.

[48] Lin H., Boylston T.D., Luedecke L.O., Shultz T.D., Conjugated linoleic acid content of Cheddar-type cheeses as affected by processing, J. Food Sci. 64 (1999) 874-878.

[49] Lin M.Y., Young C.M., Folate levels in cultures of lactic acid bacteria, Int. Dairy J. 10 (2000) 409-413.
[50] Lindmark-Månsson H., Akesson B., Antioxidative factors in milk, Br. J. Nutr. 84 (2000) S103-S110.

[51] Loor J.J., Ferlay A., Ollier A., Doreau M., Chilliard Y., Relationship among trans and conjugated fatty acids and bovine milk fat yield due to dietary concentrate and linseed oil, J. Dairy Sci. 88 (2005) 726-740.

[52] Lopez H.W., Duclos V., Coudray C., Krespine V., Feillet-Coudray C., Messager A., Demigné C., Rémésy C., Making bread with sourdough improves mineral bioavailability from reconstituted whole wheat flour in rats, Nutrition 19 (2003) 524-530.

[53] Lucey J.A., Fox P.F., Importance of calcium and phosphate in cheese manufacture: a review, J. Dairy Sci. 76 (1993) 1714-1724.

[54] Lyan B., Azais-Braesco V., Cardinault N., Tyssandier V., Borel P., Alexandre-Gouabau M.C., Grolier P., Simple method for clinical determination of 13 carotenoids in human plasma using an isocratic high-performance liquid chromatographic method, J. Chromatogr. B Biomed. Sci. Appl. 751 (2001) 297303.

[55] Marsh R., Kajda P., Ryley J., The effect of light on the vitamin $\mathrm{B}_{2}$ and the vitamin $\mathrm{A}$ content of cheese, Nahrung 38 (1994) 527-532.

[56] Mora O., Romano J.L., Gonzalez E., Ruiz F., Shimada A., Low cleavage activity of 15,15 , dioxygenase to convert beta-carotene to retinal in cattle compared with goats, is associated with the yellow pigmentation of adipose tissue, Int. J. Vitam. Nutr. Res. 70 (2000) 199-205.

[57] Moreno-Rojas R., Amaro-Lopez M.A., GarciaGimeno R.H., Zurera-Cosano G., Effects of Manchego-type cheese-making process on contents of mineral elements, Food Chem. 53 (1995) 435-439.

[58] Murphy P.A., Engelhardt R., Smith S.E., Isomerization of retinyl palmitate in fortified skim milk under retail fluorescent lighting, $\mathrm{J}$. Agric. Food Chem. 36 (1988) 592-595.

[59] Ndaw S., Bergaentzle M., Aoude-Werner D., Lahely S., Hasselmann C., Determination of folates in foods by high-performance liquid chromatography with fluorescence detection after precolumn conversion to 5-methyltetrahydrofolates, J. Chromatogr. A. 928 (2001) 77-90.

[60] Østdal H., Andersen H.J., Nielsen J.H., Antioxidative activity of urate in bovine milk, J. Agric. Food Chem. 48 (2000) 55885592.

[61] Palmer L.S., The physiological relation of plant carotenoids to the carotenoids of the cow, horse, sheep, goat, pig, and hen, J. Biol. Chem. 27 (1916) 27-32. 
[62] Panfili G., Manzi P., Pizzoferrato L., Influence of thermal and other manufacturing stresses on retinol isomerization in milk and dairy products, J. Dairy Res. 65 (1998) 253-260.

[63] Parker T.G., Dalgleish D.G., Binding of calcium ions to bovine beta-casein, J. Dairy Res. 48 (1981) 71-76.

[64] Pesek C.A., Warthesen J.J., Characterization of the photodegradation of $\beta$-carotene in aqueous model systems, J. Food Sci. 53 (1988) 1517-1520.

[65] Poiffait A., Lietaer E., Le Pavec P., Adrian J., Interrelations physico-chimiques et nutritionnelles entre la caséine et les vitamines liposolubles, Ind. Aliment. Agric., 109 (1992) 939-947.

[66] Puyol P., Perez M.D., Ena J.M., Calvo M., Interaction of $\beta$-lactoglobulin and other bovine and human whey proteins with retinol and fatty acids, Agric. Biol. Chem. 55 (1991) 2515-2520.

[67] Reif G.D., Shahani K.M., Vakil J.R., Crowe L.K., Factors affecting B-complex vitamin content of Cottage cheese, J. Dairy Sci. 59 (1976) 410-415.

[68] Rezk B.M., Haenen G.R.M.M., van der Vijgh W.J.F., Bast A., Tetrahydrofolate and 5methyltetrahydrofolate are folates with high antioxidant activity. Identification of the antioxidant pharmacophore, FEBS Lett. 555 (2003) 601-605.

[69] Sabry Z.I., Guerrant N.B., Vitamin content of pickled cheeses as influenced by production and ripening, J. Dairy Sci. 41 (1958) 925930.

[70] Sanchez-Villegas A., Martinez J.A., Prattala R., Toledo E., Roos G., Martinez-Gonzalez M.A., A systematic review of socioeconomic differences in food habits in Europe: consumption of cheese and milk, Eur. J. Clin. Nutr. 57 (2003) 917-929.

[71] Scott K.J., Bishop D.R., Nutrient content of milk and milk products: vitamins of the $B$ complex and vitamin $\mathrm{C}$ in retail cheeses, $\mathrm{J}$. Sci. Food Agric. 43 (1988) 187-192.

[72] Shahani K.M., Hathaway I.L., Kelly P.L., Bcomplex vitamin content of cheese. II. Niacin, panthotenic acid, pyridoxine, biotin, and folic acid, J. Dairy Sci. 45 (1962) 833-841.

[73] Shantha N.C., Decker E.A., Ustunol Z., Conjugated linoleic acid concentration in processed cheese, J. Am. Oil Chem. Soc. 69 (1992) 425-428.

[74] Sollberger H., Schaeren W., Collomb M., Badertscher R., Bütikofer U., Sieber R., Beitrag zur Kenntnis der Zusammensetzung von Ziegenmilch schweizerischer Herkunft, ALP Sci. 473 (2004) 1-16.

[75] Stahl W., Sies H., Antioxidant activity of carotenoids, Mol. Aspects Med. 24 (2003) 345-351.

[76] Stancher B., Zonta F., High-performance liquid chromatographic determination of carotene and vitamin a and its geometric isomers in foods. Applications to cheese analysis, J. Chromatogr. 238 (1982) 217-225.

[77] Subagio A., Morita N., Instability of carotenoids is a reason for their promotion on lipid oxidation, Food Res. Int. 34 (2001) 183-188.

[78] Subagio A., Morita N., Sawada S., Thermal isomerization of all-trans-lutein in a benzene solution, Biosci. Biotechnol. Biochem. 62 (1998) 2453-2456.

[79] Szuts E.Z., Harosi F.I., Solubility of retinoids in water, Arch. Biochem. Biophys. 287 (1991) 297-304.

[80] Thomas J.B., Duewer D.L., Kline M.C., Sharpless K.E., The stability of retinol, $\alpha$-tocopherol, trans-lycopene, and trans$\beta$-carotene in liquid-frozen and lyophilized serum, Clin. Chim. Acta 276 (1998) 75-87.

[81] Thompson J.N., Erdody P., Destruction by light of vitamin a added to milk, Can. Inst. Food Sci. Technol. J. 7 (1974) 157-158.

[82] Tong L.M., Sasaki S., McClements D.J., Decker E.A., Mechanisms of the antioxidant activity of a high molecular weight fraction of whey, J. Agric. Food Chem. 48 (2000) 1473-1478.

[83] Wigertz K., Hansen I., Hoier-Madsen M., Holm J., Jagerstad M., Effect of milk processing on the concentration of folate-binding protein (FBP), folate-binding capacity and retention of 5-methyltetrahydrofolate, Int. J. Food Sci. Nutr. 47 (1996) 315-322.

[84] Wigertz K., Svensson U.K., Jagerstad M., Folate and folate-binding protein content in dairy products, J. Dairy Res. 64 (1997) 239252.

[85] Wong N.P., Lacroix D.E., Mattingly W.A., Vestal J.H., Alford J.A., The effect of manufacturing variables on the mineral content of Cottage cheese, J. Dairy Sci. 59 (1976) 41-44.

[86] Yang A., Tume R.K., A comparison of betacarotene-splitting activity isolated from intestinal mucosa of pasture-grazed sheep, goats and cattle, Biochem. Mol. Biol. Int. 30 (1993) 209-217.

[87] Zahar M., Smith D.E., Warthesen J.J., Factors related to the light stability of vitamin a in various carriers, J. Dairy Sci. 70 (1987) 13-19. 